\title{
Efektivitas Ekstrak Kulit Buah Maja Sebagai Inhibitor pada Baja Karbon Aisi 1020 dalam Medium Korosif Nacl 3\% dengan Variasi Waktu Perendaman
}

\author{
Ismi Nurhayati, Pulung Karo Karo, dan Syafriadi \\ Jurusan Fisika FMIPA Universitas Lampung \\ Jl.Prof. Dr. Sumantri Brojonegoro No. 1 Gedung Meneng Bandar Lampung 35144 \\ E-mail: adismi1319@gmail.com
}

Diterima (28 Maret 2019), Direvisi (8 Juli 2020)

\begin{abstract}
Research has been conducted on the effectiveness of maja fruit skin extract as an inhibitor of carbon steel AISI 1020 in a corrosive medium $\mathrm{NaCl} 3 \%$ with variations in immersion time. The samples carbon steel AISI 1020 were immersed in corrosive medium $\mathrm{NaCl} 3 \%$ without being given and given the inhibitor of maja skin extract with a concentration of $0.8 \%$ for $5,15,25,35$, and 45 days. Calculation of reduction in corrosion rate is carried out by the method of weight loss. The results showed that the addition of the maja fruit skin extract inhibitor was effective in reducing the corrosion rate of the sample with the greatest efficiency at 35 days immersion, which was equal to $72.35 \%$. The results of XRD characterization show that the phase formed is pure $\mathrm{Fe}$ and $\mathrm{Fe}_{3} \mathrm{O}_{4}$ phase which is a corrosion product is immersed without inhibitor. The results of SEM characterization showed that the microstructure of the surface of the sample after immersion was there were cracks, holes, and lumps which indicated that the sample had been corroded. The results of EDS characterization show that in the soaked sample there were corrosion products in the form of $\mathrm{FeO}$ compounds whose magnitude increased every time immersion.
\end{abstract}

Keywords: Low carbon AISI 1020, corrosion inhibition, the exract of maja skin, $\mathrm{NaCl}$, XRD, and SEM-EDS.

\begin{abstract}
Abstrak. Telah dilakukan penelitian tentang efektivitas ekstrak kulit buah maja sebagai inhibitor pada baja karbon AISI 1020 dalam medium korosif $\mathrm{NaCl}$ 3\% dengan variasi waktu perendaman. Sampel baja karbon AISI 1020 direndam dalam medium korosif $\mathrm{NaCl} 3 \%$ tanpa diberi dan dengan diberi inhibitor ekstrak kulit buah maja dengan konsentrasi $0,8 \%$ selama $5,15,25,35$, dan 45 hari. Perhitungan penurunan laju korosi dilakukan dengan metode kehilangan berat. Hasil penelitian menunjukkan bahwa penambahan inhibitor ekstrak kulit buah maja efektif dalam menurunkan laju korosi sampel dengan efisiensi terbesar pada perendaman selama 35 hari, yaitu sebesar 72,35\%. Hasil karakterisasi XRD memperlihatkan bahwa fasa yang terbentuk adalah $\mathrm{Fe}$ murni dan pada sampel yang direndam tanpa inhibitor muncul juga fasa $\mathrm{Fe}_{3} \mathrm{O}_{4}$ yang merupakan produk korosi. Hasil karakterisasi SEM menunjukkan mikro struktur permukaan sampel setelah direndam yaitu terdapat retakan, lubang, dan gumpalan yang mengindikasikan bahwa sampel telah mengalami korosi. Hasil karakterisasi EDS menunjukkan bahwa pada sampel yang telah direndam terdapat produk korosi berbentuk senyawa $\mathrm{FeO}$ yang besarnya semakin meningkat ditiap waktu perendaman.
\end{abstract}

Kata kunci: Baja karbon AISI 1020, inhibitor korosi, ekstrak kulit buah maja, NaCl, XRD, dan SEM-EDS. 


\section{PENDAHULUAN}

Baja merupakan bahan yang paling banyak digunakan dalam bidang industri. Selain harganya lebih murah dibanding bahan yang lain, baja juga memiliki sifat yang bervariasi sehingga bentuk dan sifatnya dapat disesuaikan dengan kebutuhan [1](Surdia dan Saito, 1999). Selain itu, baja jenis ini juga mudah dilas [2] (ASM handbook, 1993). Baja karbon rendah adalah klasifikasi baja yang banyak digunakan untuk bahan roda gigi, mur, baut, rangka kendaraan dan juga pada perkapalan [3] (Supriadi, 2010). Salah satu baja karbon rendah adalah baja AISI 1020 yang sering diaplikasikan pada sistem perpipaan kapal laut. Pipa-pipa ini merupakan tempat mengalirnya uap ataupun cairan yang berupa air, bahan bakar, ataupun minyak pelumas. Tekanan, temperatur dan jenis fluida yang mengalir dalam pipa dapat mengakibatkan korosi yang akhirnya mempengaruhi kekuatan dan umur pipa [4] (Triastuti dan Purwanto, 2012).

Hampir semua logam dan baja yang digunakan dalam kehidupan sehari-hari mulai dari struktur jembatan, rangka mobil, peralatan rumah tangga, alat-alat kesehatan, peralatan di lingkungan pabrik petrokimia, dan kapal-kapal laut mengalami korosi [5] (Ali dkk., 2014). Sejauh ini, penambahan inhibitor merupakan salah satu cara yang paling efektif untuk mencegah korosi. Inhibitor korosi adalah suatu zat yang bila ditambahkan ke dalam suatu lingkungan, dapat menurunkan laju penyerangan korosi lingkungan terhadap suatu logam. Jenisjenis inhibitor menurut bahan dasarnya dapat dibagi dua, yaitu inhibitor organik dan inhibitor anorganik [6] (Wahyuni dkk., 2013). Contoh inhibitor organik yaitu ekstrak daun teh [7] (Sari dkk., 2013) dan ekstrak ubi ungu [8] (Nugroho, 2011).

Pada penelitian kali ini inhibitor yang digunakan adalah inhibitor organik yang terbuat dari ekstrak kulit buah maja. Baja yang digunakan adalah baja karbon AISI
1020 yang direndam dalam medium korosif $\mathrm{NaCl}$ 3\% dengan konsentrasi inhibitor ekstrak kulit buah maja sebesar $0,8 \%$ dan lama waktu perendaman bervariasi selama 5 , 15, 25, 35, dan 45 hari. Laju korosi pada baja dihitung menggunakan metode kehilangan berat. Sampel baja hasil korosi akan dikarakterisasi dengan XRD, SEM, dan EDS. Dari hasil penelitian ini diharapkan dapat diketahui efisiensi inhibitor ekstrak kulit buah maja $0,8 \%$ dalam mengurangi laju korosi baja karbon AISI 1020 yang direndam dalam medium korosif $\mathrm{NaCl} 3 \%$ selama 5, 15, 25, 35, dan 45 hari.

\section{METODE PENELITIAN}

Penelitian ini dimulai dengan pengambilan kulit buah maja dari 7 buah maja segar, lalu dikeringkan dengan cara dijemur di bawah sinar matahari selama 14 hari dan dioven pada suhu $100{ }^{\circ} \mathrm{C}$ selama 8 jam untuk menghilangkan kadar air. Kemudian kulit yang telah kering diblender hingga menjadi serbuk. Serbuk kulit buah maja sebanyak 440 gram selanjutnya dimasukkan ke dalam botol yang berisi etanol 96\% sebanyak 2 liter dan dibiarkan selama 1 hari. Hasil ekstraksi disaring dan filtrat diuapkan menggunakan alat penguap putar vakum (rotary evaporator) dengan kecepatan $200 \mathrm{rpm}$ pada suhu $45-50{ }^{\circ} \mathrm{C}$ hingga menghasilkan ekstrak pekat.

Selanjutnya baja ukuran panjang $8 \mathrm{~mm}$, lebar $8 \mathrm{~mm}$, tebal $5 \mathrm{~mm}$, dan lubang dengan diameter $3 \mathrm{~mm}$ dibersihkan dengan amplas dan ditimbang. Setelah itu pembuatan larutan $\mathrm{NaCl} 3 \%$ dengan cara menambahkan 3 gram $\mathrm{NaCl}$ ke dalam 100 $\mathrm{ml}$ aquabides. Lalu baja yang telah ditimbang dimasukkan ke dalam medium korosif $\mathrm{NaCl} 3 \%$ tanpa dan dengan inhibitor ekstrak kulit buah maja 0,8\% masingmasing selama 5, 15, 25, 35, dan 45 hari. Perendaman sampel ditunjukkan pada Gambar 1. 




Gambar 1. Perendaman sampel (a) tanpa inhibitor (b) dengan inhibitor.

Setelah direndam selama 5, 15, 25, 35, dan 45 hari sampel kemudian dibersihkan dan ditimbang kembali sehingga didapatkan selisih massa awal dan massa akhir sampel, lalu sampel dikarakterisasi XRD, SEM, dan EDS.

Perhitungan laju korosi dilakukan dengan persamaan:

$$
C R=\frac{K \Delta m}{A t \rho}
$$

Sementara untuk menghitung efisiensi inhibitor menggunakan persamaan

$$
\eta(\%)=\frac{\left(C R_{\text {uninhibited }}-C R_{\text {inhibited }}\right)}{C R_{\text {uninhibited }}} \times 100 \%
$$

\section{HASIL DAN PEMBAHASAN}

\section{Laju Korosi Baja Karbon AISI 1020 setelah Perendaman}

Hasil penelitian perendaman baja karbon AISI 1020 dalam medium korosif $\mathrm{NaCl} 3 \%$ dengan diberi inhibitor ekstrak kulit buah maja $0,8 \%$ dan tanpa diberi inhibitor dengan waktu perendaman selama $5,15,25,35$, dan 45 dapat dilihat pada Gambar 2.



Gambar 2. Hubungan antara laju korosi baja karbon AISI 1020 terhadap waktu perendaman.

Berdasarkan Gambar 2 dapat dilihat bahwa penambahan inhibitor ekstrak kulit buah maja menyebabkan penurunan laju korosi di tiap waktu perendaman. Laju korosi sampel yang direndam tanpa inhibitor lebih besar dari sampel yang direndam dengan tambahan inhibitor. Sesuai dengan penelitian yang dilakukan oleh Rasitiani [9] tentang pengaruh konsentrasi ekstrak kulit buah maja terhadap laju korosi baja karbon api 51 pada medium $\mathrm{NaCl}$ dan $\mathrm{H}_{2} \mathrm{SO}_{4}$. Sampel yang direndam dalam medium korosif $\mathrm{H}_{2} \mathrm{SO}_{4} \quad 3 \%$ selama 35 hari, laju korosi yang dihasilkan sebesar 80,17 x $10^{4}$ $\mathrm{mm} / \mathrm{y}$, sedangkan saat diberi tambahan inhibitor ekstrak kulit buah maja laju korosinya turun menjadi $19,85 \times 10^{4} \mathrm{~mm} / \mathrm{y}$. Hal ini menunjukkan bahwa inhibitor ekstrak kulit buah maja efektif dalam menghambat laju korosi baja karbon AISI 1020. Berdasarkan hasil perbandingan laju korosi sampel tanpa dan dengan diberi inhibitor, maka dapat dilihat efisiensi inhibitor ekstrak kulit buah maja sebesar $0,8 \%$ dalam menghambat laju korosi baja karbon AISI 1020 di tiap waktu perendaman pada Gambar 3. 




Gambar 3. Hubungan antara efisiensi inhibitor ekstrak kulit buah maja $0,8 \%$ terhadap waktu perendaman.

Berdasarkan Gambar 3 dapat dilihat bahwa efisiensi inhibitor ekstrak kulit buah maja semakin hari semakin meningkat sampai pada perendaman selama 35 hari yaitu sebesar $72,7 \%$, sementara pada perendaman 45 hari besar efisiensi inhibitor ekstrak kulit buah maja mengalami penurunan menjadi $68,8 \%$. Penurunan laju korosi dan kenaikkan efisiensi ini disebabkan adanya ekstrak kulit buah maja yang menutupi sampel sehingga pengkorosian tidak optimal, namun ketika perendaman lebih dari 35 hari, larutan ekstrak kulit buah maja mengalami kejenuhan, sehingga tidak dapat lagi menutupi permukaan sampel dengan sempurna, akhirnya sampel lebih mudah terkorosi. Hal ini sesuai dengan penelitian yang dilakukan oleh Hidayat dan Sumarji [10] bahwa waktu perendaman selama 35 hari merupakan waktu yang paling optimum untuk inhibitor ekstrak kulit buah maja dalam menghambat laju korosi yang terjadi selama 45 hari.

\section{Analisis XRD (X-Ray Diffraction)}

Karakterisasi dengan XRD dilakukan untuk mengetahui fasa yang terbentuk dalam sampel setelah perendaman. Pengujian ini dilakukan pada sampel AI.25, AI.35, AI.45, dan AT.45. Difraktogram sampel yang direndam dengan inhibitor dan tanpa inhibitor ditunjukkan pada Gambar 4.

Gambar 4 menunjukkan pengujian XRD dengan panjang gelombang yang digunakan sebesar 1,54060 A. Dari hasil XRD sampel yang direndam dengan inhibitor (AI.45) terdapat 3 puncak yang tajam, sedangkan sampel yang direndam tanpa inhibitor (AT.45)terdapat 4 puncak yang tajam yang mengindikasikan terbentuknya fasa kristal. Untuk mengetahui fasa yang terbentuk dilakukan analisis kualitatif terhadap data hasil XRD dengan metode search match analysis atau metode pencocokan data. yang diperoleh dengan pangkalan data PDF (Power Diffraction File data base). Software yang digunakan untuk mengidentifikasi adalah PCPDFWIN versi 1.3 JCPSD-ICDD 1997. Adapun parameter yang dibandingkan yaitu $2 \theta\left(^{\circ}\right)$ dan d $(\AA)$. Berdasarkan hasil search match analysis atau pencocokan data sampel diperoleh fasa $\mathrm{Fe}$ (besi) dengan data PCPDFWIN nomor 26-1136 dan 06-0696. Perbandingan antara hasil penelitian sampel AT.45 dan AI.45 dengan program PCPDFWIN ditunjukkan pada Tabel 1 dan Tabel 2.

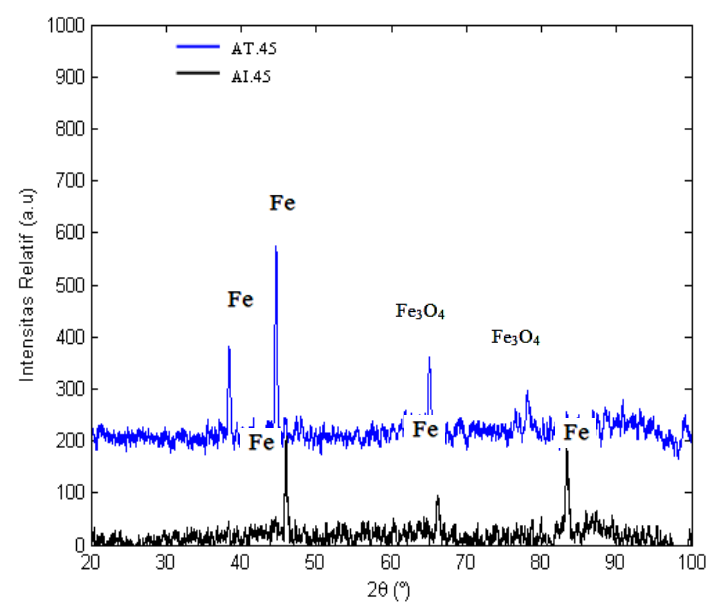

Gambar 4. Difraktogram hasil XRD sampel yang direndam dengan inhibitor dan tanpa inhibitor selama 45 hari. 
Tabel 1. Perbandingan hasil penelitian sampel AT.45 dengan data PCPDFWIN nomor 26-1136 dan 06-0696.

\begin{tabular}{|c|c|c|c|c|c|c|}
\hline \multirow{2}{*}{ No. } & \multicolumn{2}{|c|}{ Data penelitian } & \multicolumn{2}{|c|}{ Data standar PCPDFWIN } & \multirow{2}{*}{$\Delta \mathbf{d}(\AA)$} & \multirow{2}{*}{ Fasa } \\
\hline & $2 \theta\left({ }^{\circ}\right)$ & $\mathrm{d}(\AA)$ & $2 \theta(\circ)$ & $\mathrm{d}(\AA)$ & & \\
\hline 1. & 38,4045 & 2,34396 & 38,522 & 2,3350 & 0,00896 & $\mathrm{Fe}_{3} \mathrm{O}_{4}$ \\
\hline 2. & 44,6060 & 2,03143 & 44,671 & 2,0268 & 0,00463 & $\mathrm{Fe}$ \\
\hline 3. & 65,0669 & 1,43352 & 65,018 & 1,4332 & 0,00032 & $\mathrm{Fe}$ \\
\hline 4. & 78,1528 & 1,22302 & 77,249 & 1,2340 & 0,01098 & $\mathrm{Fe}_{3} \mathrm{O}_{4}$ \\
\hline
\end{tabular}

Tabel 2. Perbandingan hasil penelitian sampel AI.45 dengan data PCPDFWIN nomor 06-0696

\begin{tabular}{lcccccc}
\hline \multirow{2}{*}{ No. } & \multicolumn{2}{c}{ Data penelitian } & \multicolumn{2}{c}{ Data standar PCPDFWIN } & \multirow{2}{*}{$\Delta$ d $(\AA)$} & \multirow{2}{*}{ Fasa } \\
\cline { 2 - 5 } & $2 \theta(\circ)$ & $\mathrm{d}(\AA)$ & $2 \theta(\circ)$ & $\mathrm{d}(\AA)$ & & \\
\hline 1. & 45,9919 & 1,97339 & 44,671 & 2,0268 & 0,05341 & $\mathrm{Fe}$ \\
2. & 66,0812 & 1,42396 & 65,018 & 1,4332 & 0,01924 & $\mathrm{Fe}$ \\
3. & 83,3569 & 1,15939 & 82,329 & 1,1702 & 0,01081 & $\mathrm{Fe}$ \\
\hline
\end{tabular}

Berdasarkan Tabel 1 dapat dilihat bahwa hasil pencocokan dengan PCPDFWIN menyatakan puncak pertama dan keempat pada sampel AT.45 mempunyai fasa magnetit $\left(\mathrm{Fe}_{3} \mathrm{O}_{4}\right)$, puncak kedua dan ketiga mempunyai fasa besi $(\mathrm{Fe})$. Fasa magnetit terbentuk karena adanya interaksi antara $\mathrm{Fe}$ dengan $\mathrm{OH}^{-}$. Sedangkan pada Tabel 2 menunjukkan pada sampel AI.45 ketiga puncak yang terbentuk memiliki fasa besi.

Selain perbandingan antara sampel yang direndam dengan dan tanpa inhibitor, pada penelitian ini juga akan dilihat pengaruh lama waktu perendaman pada sampel yang direndam dengan diberi inhibitor. Difraktogram sampel yang direndam dengan diberi inhibitor selama 25, 35, dan 45 hari dapat dilihat pada Gambar 5.

Berdasarkan Gambar 5 dapat dilihat bahwa tidak terdapat perbedaan yang signifikan dari ketiga sampel. Masingmasing menghasilkan 3 puncak yang tajam. Pada sampel yang direndam selama 25 hari intensitas yang dihasilkan sangat tinggi, hal ini mengindikasikan bahwa pada sampel masih banyak mengandung Fe. Selanjutnya dari puncak-puncak yang dihasilkan dilakukan pencocokan data menggunakan PCPDFWIN. Perbandingan antara hasil penelitian sampel AI.25 dan AI.35 dengan program PCPDFWIN ditunjukkan pada Tabel 3 dan Tabel 4.



Gambar 5. Difraktogram hasil XRD sampel yang direndam menggunakan inhibitor selama 25, 35, dan 45 hari.

Tabel 3. Perbandingan hasil penelitian sampel AI.25 dengan data PCPDFWIN nomor 06-0696.

\begin{tabular}{lccccccc}
\hline \multirow{2}{*}{ No. } & \multicolumn{2}{c}{ Data penelitian } & \multicolumn{2}{c}{ Data standar PCPDFWIN } & \multirow{2}{*}{$\Delta$ d $(\AA)$} & \multirow{2}{*}{ Fasa } \\
\cline { 2 - 5 } & $2 \theta(\circ)$ & $\mathrm{d}(\AA)$ & $2 \theta(\circ)$ & $\mathrm{d}(\AA)$ & & \\
\hline 1. & 45,7380 & 1,98375 & 44,671 & 2,0268 & 0,04305 & $\mathrm{Fe}$ & $\mathrm{Fe}$ \\
2. & 66,0662 & 1,41424 & 65,018 & 1,4332 & 0,01896 & $\mathrm{Fe}$ \\
3. & 83,2433 & 1,16069 & 82,329 & 1,1702 & 0,10330 & $\mathrm{Fe}$ \\
\hline
\end{tabular}


Tabel 4. Perbandingan hasil penelitian sampel AI.35 dengan data PCPDFWIN nomor 06-0696.

\begin{tabular}{lcccccc}
\hline \multirow{2}{*}{ No. } & \multicolumn{2}{c}{ Data penelitian } & \multicolumn{2}{c}{ Data standar PCPDFWIN } & \multirow{2}{*}{$\Delta \mathrm{d}(\AA)$} & \multirow{2}{*}{ Fasa } \\
\cline { 2 - 5 } & $2 \theta(\circ)$ & $\mathrm{d}(\AA)$ & $2 \theta(\circ)$ & $\mathrm{d}(\AA)$ & & \\
\hline 1. & 45,8661 & 1,97851 & 44,671 & 2,0268 & 0,78341 & $\mathrm{Fe}$ \\
2. & 66,0778 & 1,41402 & 65,018 & 1,4332 & 0,01918 & $\mathrm{Fe}$ \\
3. & 83,3521 & 1,15945 & 82,329 & 1,1702 & 0,01075 & $\mathrm{Fe}$ \\
\hline
\end{tabular}

Berdasarkan Tabel 3 dan Tabel 4 dapat dilihat bahwa hasil pencocokkan data penelitian sampel AI.25 dan AI.35 dengan PCPDFWIN 06-0696 menunjukkan bahwa ketiga puncaknya memiliki fasa besi. Ketiga sampel yang direndam dengan diberi tambahan inhibitor menghasilkan tiga puncak dengan fasa dan bidang yang sama. Hal ini sesuai dengan penelitian yang dilakukan oleh Bundjali dkk [11] bahwa baja karbon rendah menghasilkan fasa Fe.

\section{Analisis SEM-EDS (Scanning Electron Microscopy-Energy Dispersive Spectroscopy)}

Analisis SEM bertujuan untuk mengetahui struktur mikro pada permukaan sampel. Selain analisis SEM juga dilakukan analisis EDS untuk mengetahui komposisi unsur atau senyawa yang terdapat pada sampel. Analisis SEM dan EDS dilakukan pada sampel AT.45, AI.25, AI.35, dan
AI.45. Hasil SEM sampel yang direndam tanpa inhibitor dan dengan inhibitor ditunjukkan pada Gambar 6.

Pada Gambar 6 (a) dan (b) terlihat perbandingan pada perbesaran $3000 \mathrm{x}$ bisa dilihat bahwa pada sampel yang direndam tanpa inhibitor lebih banyak terlihat gumpalan yang berpencar dan hanya terlihat sedikit retakkan, sementara pada sampel yang direndam menggunakan inhibitor terlihat lebih banyak retakan dan masih terlihat lebih rata.

Selanjutnya adalah hasil EDS sampel AT.45 dan AI.45. Grafik analisis hasil EDS sampel AT.45 dengan AI.45 ditunjukkan pada Gambar 7 (a) dan (b).

Gambar 7 (a) dan (b) menunjukkan unsur-unsur yang terdapat pada sampel AT.45 dan AI.45 berdasarkan hasil karakterisasi EDS. Dari gambar grafik tersebut maka dapat dilihat komposisi yang ada pada sampel AT.45 dan AI.45 ditunjukkan pada Tabel 5.

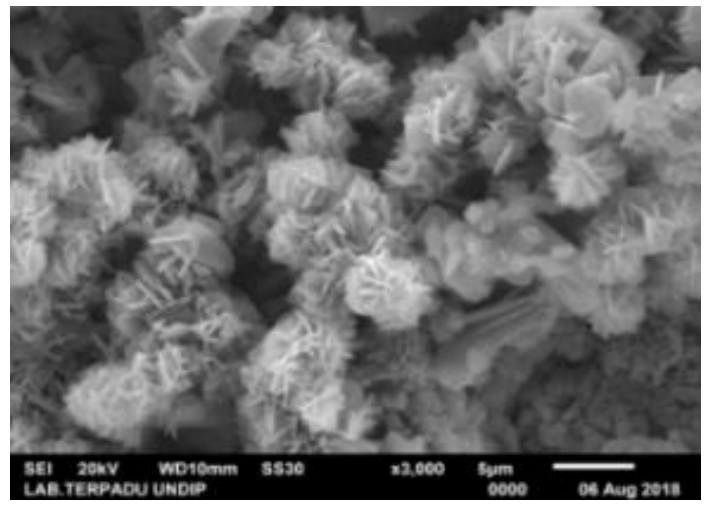

(a)

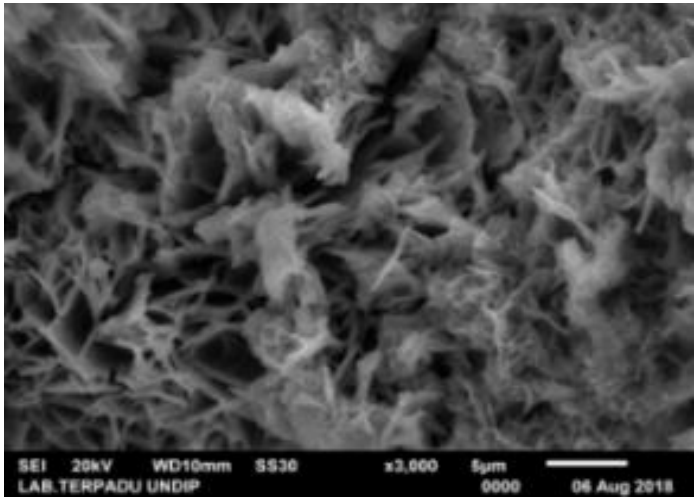

(b)

Gambar 6. Hasil SEM sampel (a) AT.45 (b) AI.45 dengan perbesaran 3000x. 


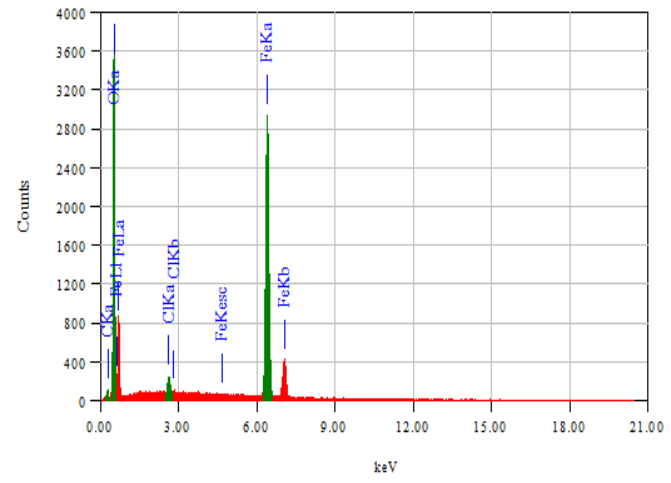

(a)

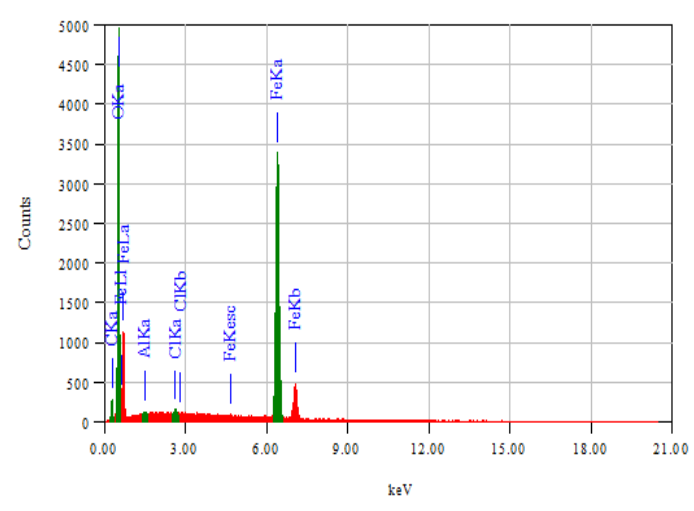

(b)

Gambar 7. Grafik analisis hasil EDS sampel AISI 1020 (a) tanpa inhibitor (b) dengan inhibitor selama 45 hari.

Tabel 5. Perbandingan hasil analisis EDS sampel AT.45 dan AI.45.

\begin{tabular}{cccccc}
\hline \multicolumn{2}{c}{ Persentase $(\%)$} & \multicolumn{3}{c}{ Persentase(\%) } \\
\hline Unsur & $\mathrm{AT} .45$ & $\mathrm{AI} .45$ & Senyawa & AT.45 & AI.45 \\
\hline $\mathrm{C}$ & 5,61 & 12,23 & $\mathrm{C}$ & 18,80 & 12,23 \\
$\mathrm{O}$ & 20,76 & 19,58 & - & - & - \\
$\mathrm{Al}$ & - & 0,22 & $\mathrm{Al}_{2} \mathrm{O}_{3}$ & - & 0,42 \\
$\mathrm{Cl}$ & 1,18 & 0,32 & $\mathrm{Cl}$ & 1,18 & 0,32 \\
$\mathrm{Fe}$ & 72,46 & 67,65 & $\mathrm{FeO}$ & 93,21 & 87,03 \\
\hline
\end{tabular}

Berdasarkan Tabel 5 dapat dilihat bahwa unsur-unsur yang terdapat pada sampel AT.45 adalah $\mathrm{C}, \mathrm{O}, \mathrm{Cl}$, dan Fe. Sementara pada sampel AI.45 terdapat C, O, $\mathrm{Cl}, \mathrm{Fe}$, dan Al. Terdapat unsur Al karena menurut hasil pengujian OES yang dilakukan oleh Aditama [12], Al merupakan salah satu unsur penyusun baja karbon AISI 1020. Senyawa $\mathrm{FeO}$ yang terbentuk pada sampel AT.45 lebih tinggi dengan persentase sebesar $93,21 \%$ sedangkan pada sampel AI.45 persentase senyawa $\mathrm{FeO}$ yang terbentuk sebesar 87,03\%. Hal ini menunjukkan bahwa sampel yang direndam tanpa menggunakan inhibitor lebih mudah terkorosi dibanding sampel yang direndam dengan tambahan inhibitor ekstrak kulit buah maja.

Untuk melihat pengaruh lama waktu perendaman pada sampel yang direndam dengan diberi inhibitor maka dilakukan analisis pada sampel AI.25, AI.35, dan
AI.45. Hasil SEM AI.25, AI.35, dan AI.45 ditunjukkan pada Gambar 8.

Perbandingan pada perbesaran $3000 \mathrm{x}$ dapat dilihat pada Gambar 8 (a), (b), dan (c). Pada sampel AI.25 terlihat retakkan dan gumpalan yang berlubang dan hampir tersebar merata, pada sampel AI.35 lebih dominan terbentuk retakkan, dan permukaannya masih terlihat lebih halus, lalu pada sampel AI.45 terlihat retakkan yang besar dan lubang-lubang berukuran kecil yang hampir merata. Retakan dan lubang merupakan faktor utama penyebab terjadinya korosi, karena keduanya adalah jalan masuk untuk oksigen. Saat oksigen sudah masuk maka akan menarik elektron dari $\mathrm{Fe}$ untuk keluar, sehingga $\mathrm{Fe}$ akan kekurangan elektron dan terjadilah karat.

Selanjutnya untuk melihat pengaruh waktu perendaman terhadap pengkorosian sampel dapat dilihat dari hasil EDS sampel yang direndam dengan tambahan inhibitor 
selama 25, 35, dan 45 hari. Hasil EDS sampel AI.25 dan AI.45 dapat dilihat pada Gambar 9.

Gambar 9 (a) dan (b) menunjukkan unsur-unsur yang terdapat pada sampel AI.25 dan AI.35 setelah perendaman.
Berdasarkan hasil EDS sampel AI.25, AI.35, dan AI.45 dapat dilihat perbandingan persentase unsur yang dihasilkan masingmasing sampel. Hasil EDS sampel AI.25, AI.35, dan AI.45 ditunjukkan pada Tabel 6.

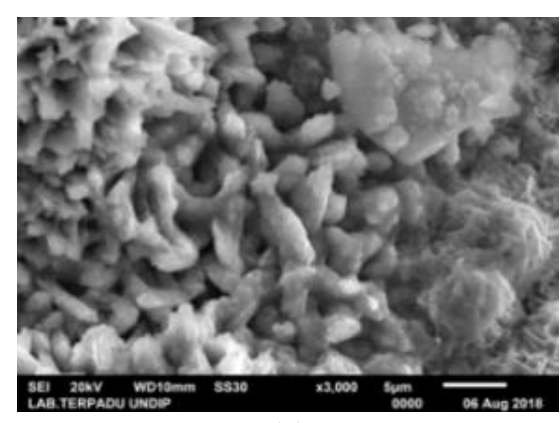

(a)

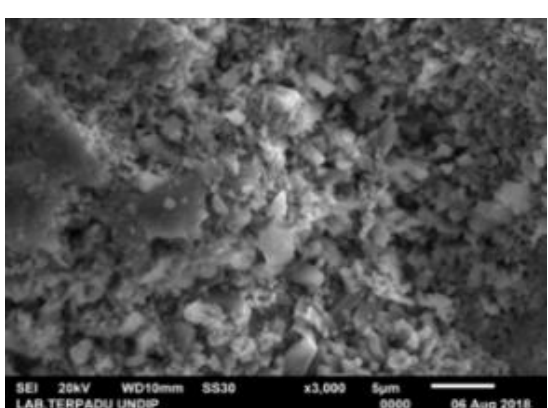

(b)

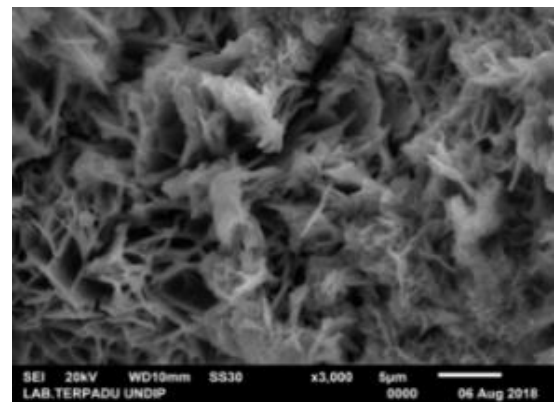

(c)

Gambar 8. Hasil SEM sampel (a) AI.25 (b) AI.35 (c) AI.45 dengan perbesaran 3000 x.

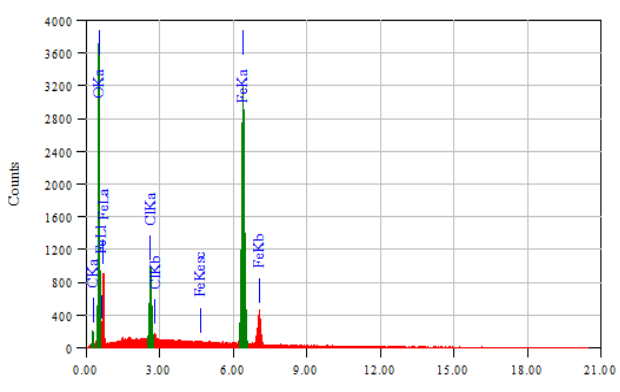

(a)

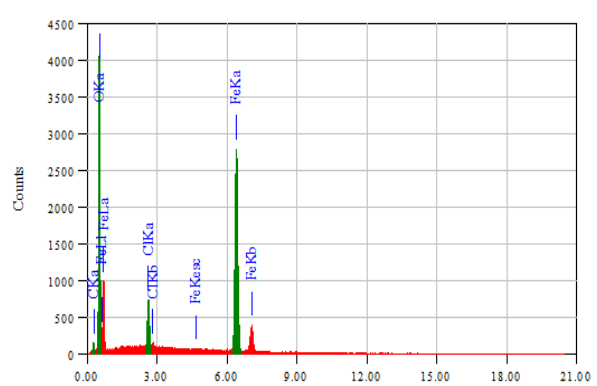

(b)

Gambar 9. Grafik analisis hasil EDS sampel AISI 1020 dengan inhibitor selama (a) 25 hari dan (b) 35 hari.

Tabel 6. Perbandingan hasil analisis EDS sampel AI.25, AI.35, dan AI.45.

\begin{tabular}{cccccccc}
\hline \multicolumn{3}{c}{ Persentase (\%) } & & \multicolumn{3}{c}{ Persentase(\%) } \\
\hline Unsur & AI.25 & AI.35 & AI.45 & Senyawa & AI.25 & AI.35 & AI.45 \\
\hline $\mathrm{C}$ & 11,44 & 9,22 & 12,23 & $\mathrm{C}$ & 11,44 & 9,22 & 12,23 \\
$\mathrm{O}$ & 18,58 & 19,26 & 19,58 & - & - & - & - \\
$\mathrm{Al}$ & - & - & 0,22 & $\mathrm{Al}_{2} \mathrm{O}_{3}$ & - & - & 0,42 \\
$\mathrm{Cl}$ & 5,12 & 4,32 & 0,32 & $\mathrm{Cl}$ & 5,12 & 4,32 & 0,32 \\
$\mathrm{Fe}$ & 64,86 & 67,21 & 67,65 & $\mathrm{FeO}$ & 83,44 & 86,47 & 87,03 \\
\hline
\end{tabular}


Berdasarkan Tabel 6 dapat dilihat bahwa unsur-unsur yang terdeteksi pada masing-masing sampel sama, dan pada sampel AI.45 terdeteksi juga unsur Al dimana unsur $\mathrm{Al}$ termasuk salah satu unsur penyusun baja karbon AISI 1020. Perbedaan hasil ketiga sampel salah satunya dapat dilihat dari persentase senyawa $\mathrm{FeO}$ yang terbentuk, dimana senyawa $\mathrm{FeO}$ merupakan produk korosi. Besar senyawa $\mathrm{FeO}$ pada sampel AI.25 yaitu 83,44\%, pada AI.35 sebesar 86,47\%, dan pada AI.45 sebesar $87,03 \%$. Hal ini menunjukkan bahwa semakin lama waktu perendaman, maka sampel yang direndam semakin terkorosi sehingga produk korosi yang dihasilkan semakin meningkat.

\section{KESIMPULAN}

Penambahan inhibitor ekstrak kulit buah maja sebesar $0,8 \%$ dapat menurunkan laju korosi pada perendaman selama 5, 15, 25, 35, dan 45 hari dengan efisiensi terbesar pada perendaman selama 35 hari, yaitu sebesar 72,35\%. Hasil karakterisasi XRD memperlihatkan bahwa fasa yang terbentuk adalah $\mathrm{Fe}$ murni dan pada sampel yang direndam tanpa inhibior muncul juga fasa $\mathrm{Fe}_{3} \mathrm{O}_{4}$ yang merupakan produk korosi. Hasil karakterisasi SEM menunjukkan mikro struktur permukaan sampel setelah direndam yaitu terdapat retakan, lubang, dan gumpalan yang mengindikasikan bahwa sampel telah mengalami korosi. Hasil karakterisasi EDS menunjukkan bahwa pada sampel yang telah direndam terdapat produk korosi berbentuk senyawa $\mathrm{FeO}$ yang besarnya semakin meningkat ditiap waktu perendaman.

\section{DAFTAR PUSTAKA}

[1] Surdia, T. dan Saito, S. 1999. Pengetahuan Bahan Teknik. Pradya Paramita. Jakarta.
[2] ASM Handbook. 1993. Properties and Selection : Iron Steel and High Performance Alloys. Tenth Edition. Metals Handbook.United States of America. Pp. 249-257.

[3] Supriadi, H. 2010. Studi Eksperimental tentang Pengaruh Variasi Rapat Arus pada Hard Chrome Elektroplating terhadap Karakterisasi Permukaan Baja Karbon Rendah. Jurnal Mechanical. Vol. 1. No. 1. Pp. 1-6.

[4] Triastuti, W.E. dan Purwanto ,D.B. 2012. Efek Penambahan Ion Tartrate terhadap Elektrodeposisi $\mathrm{Mn}-\mathrm{Cu}$ pada Pipa Baja Karbon. Jurnal Kapal. Vol. 9. No. 3. Pp. 167-170.

[5] Ali, F., Saputri, D., dan Nugroho, R.F. 2014. Pengaruh Waktu Perendaman dan Konsentrasi Ekstrak Daun Jambu Biji (Psidium guajava, Linn) sebagai Inhibitor terhadap Laju Korosi Baja SS 304 dalam Larutan Garam dan Asam. Jurnal Teknik Kimia. Vol. 20. No. 1. Pp. 28-36.

[6] Wahyuni, M., Djamas, D., dan Ratnawulan. 2013. Pengaruh Waktu Perendaman Baja dengan Ekstrak Buah Pinang dan $\mathrm{HCl}$ Terhadap Laju Korosi dan Potensial Logam. Jurnal Pillar Of Physics. Vol. 2. Pp. 59-67.

[7] Sari, D.M., Handani, S., dan Yetri, Y. 2013. Pengendalian Laju Korosi Baja St-37 dalam Medium Asam Klorida dan Natrium Klorida menggunakan Inhibitor Ekstrak Daun Teh (Camelia sinensis). Jurnal Poli Rekayasa. Vol. 8. No. 2. Pp. 76-85.

[8] Nugroho, A. 2011. Pengaruh Penambahan Inhibitor Organik Ekstrak Ubi Ungu terhadap Laju Korosi pada Material 
Baja Low Carbon di Lingkungan $\mathrm{NaCl} 3 \%$. Skripsi. Universitas Indonesia. Depok.

[9] Rasitiani, A. 2018. Pengaruh Konsentrasi Ekstrak Kulit Buah Maja terhadap Laju Korosi Baja Karbon Api 51 dengan Media Nacl 3,5\% dan $\mathrm{H} 2 \mathrm{SO} 4$ 3\%. Skripsi. Universitas Lampung.

[10] Hidayat, I.F.dan Sumarji. 2016. Pengaruh Konsentrasi Ekstrak Kulit Buah Maja terhadap Laju Korosi Baja Karbon A53 dengan Media Air Laut. Jurnal Rotor. Vol. 9. No. 1. Pp. 24-28.
[11] Bundjali, B.N., Surdia, M., Liang, B.N., dan Bambang. 2006. Pelarutan Besi Selektif pada Korosi Baja Karbon dalam Larutan Buffer Asetat, Natrium Bikarbonat-CO2 Jenuh. Journal Of Science. Vol. 38A. Pp. 149-161.

[12] Aditama, R.Y. 2018. Efektivitas Ekstrak Daun Pepaya (Carica Papaya L) sebagai Inhibitor pada Baja Karbon AISI 1020 dalam Medium Korosif Nacl 3\%. Skripsi. Universitas Lampung. 